\title{
Ribbon growth on substrate (RGS) silicon solar cells with microwave-induced remote hydrogen plasma passivation and efficiencies exceeding $11 \%$
}

\author{
M. Spiegel ${ }^{a, *}$, C. Zechnera, B. Bitnar ${ }^{\mathrm{a}}$, G. Hahnª, W. Jooss ${ }^{\mathrm{a}}$, \\ P. Fath ${ }^{\mathrm{a}}$, G. Willeke ${ }^{\mathrm{a}}$, E. Bucher ${ }^{\mathrm{a}}$, H.-U. Höfs ${ }^{\mathrm{b}}$, C. Häßler ${ }^{\mathrm{b}}$ \\ ${ }^{a}$ University of Konstanz, Faculty of Physics, P.O. Box X916, D-78457 Konstanz, Germany \\ ${ }^{\mathrm{b}}$ Bayer AG, Rheinuferstr. 7-9, D-47829 Krefeld-Uerdingen, Germany
}

\begin{abstract}
For the first time efficiencies above $11 \%$ for solar cells $\left(4 \mathrm{~cm}^{2}\right)$ based on Bayer ribbon growth on substrate (RGS) crystalline silicon have been demonstrated including mechanical V-structuring of the front surface, aluminum-gettering, microwave-induced remote hydrogen plasma (MIRHP) passivation and PECVD $\mathrm{SiN} / \mathrm{SiO}_{2}$ double-layer antireflection coating. MIRHP alone resulted in absolute improvements in the open-circuit voltage of $27 \mathrm{mV}$, in the shortcircuit current density of $2.8 \mathrm{~mA} \mathrm{~cm}^{-2}$ and in the cell efficiency of $1.9 \%$ leading to an open-circuit voltage of $538 \mathrm{mV}$ and an efficiency of $11.1 \%$. (C) 1998 Elsevier Science B.V. All rights reserved.
\end{abstract}

Keywords: Hydrogen passivation; Ribbon growth on substrate; Multicrystalline silicon; Solar cells

\section{Introduction}

Different sources estimate the silicon wafer share to be above $\frac{1}{3}$ of the total cost of a crystalline silicon photovoltaic module [1,2]. The recent European APAS study $[3,4]$ has shown that this number will further increase in a very large scale

\footnotetext{
*Corresponding author. Tel.: + 497531882 082; fax: + 497531883895 .
} 
(500 MWp/y) module fabrication based on standard cast multicrystalline silicon (mc-Si).

For the cost reduction of the mc-Si solar materials and cells intensive research activities have been directed to two major fields: the development of thin-film mc-Si solar cells on foreign substrates $[5,6]$ or self-supporting $[7,8]$, and the development of ribbon Si production techniques such as the edge defined film feed growth (EFG) process [9], the spin-casting concept [10] as well as the ribbon growth on substrate (RGS) process [11]. The ribbon techniques are aiming at a direct deposition of the $\mathrm{Si}$ sheets which avoids material losses due to wafer casting as well as cutting and enables high production rates. Among those the RGS technique is distinguished by a very fast process which relies on the casting of a layer of molten silicon on a supporting substrate with the crystallization front lying nearly parallel to the plane of the ribbon. At the end of the process the wafer is automatically separated from the reusable substrate. With this production technique the costs for a Si wafer can be drastically reduced [11].

An efficiency of $10.4 \%$ was reported [12] based on a $30 \mu \mathrm{m}$ thick epitaxially grown silicon layer on highly doped RGS. In contrast to this research the efficiency remained below $10 \%$ so far with RGS sheets as active solar cell material. The efficiency of "active" RGS solar cells is supposed to be limited by the interaction of high oxygen concentrations above $10^{18} \mathrm{~cm}^{-3}$, high defect densities in the range of $10^{5}-10^{7} \mathrm{~cm}^{-2}$ and the presence of metal impurities [13]. Recently, for the first time, the milestone of a $10 \%$ efficiency with RGS as the base material has been achieved in our laboratory using aluminum gettering and mechanical $\mathrm{V}$-structuring of the front surface [14].

Additionally, in the last few years the microwave-induced remote hydrogen plasma (MIRHP) process has been shown to be a very effective technique for defect passivation of several multicrystalline silicon (mc-Si) base materials [15-20]. In the present work we applied the MIRHP to RGS solar cells, which resulted in the reported efficiency of $11.1 \%$ and an open-circuit voltage of $538 \mathrm{mV}$.

\section{Experimental}

RGS sheets used in this study had a thickness of about $300 \mu \mathrm{m}$ and an average crystal grain diameter of approximately $0.5 \mathrm{~mm}$. In order to maintain consistency in the material quality and to exclude possible variations due to the solar cell processing four solar cells with an area of $4 \mathrm{~cm}^{2}$, referred to hereafter as A, B, C and D, were processed together on one $25 \mathrm{~cm}^{2}$ RGS wafer.

Solar cell processing started with a levelling of the uneven front surface of the RGS wafer with a planarisation blade mounted on a conventional silicon dicing saw to enable the usage of photolithography and to remove the segregation layer of about $25 \mu \mathrm{m}$ on top of the wafer. Afterwards the saw damage and a carbon rich layer on the back surface has been taken away in a defect etching step. Then the front surface was mechanically textured by using a beveled saw blade leading to a V-groove like pattern with a groove depth and pitch of about $60 \mu \mathrm{m}$. The emitter was formed by phosphorus 


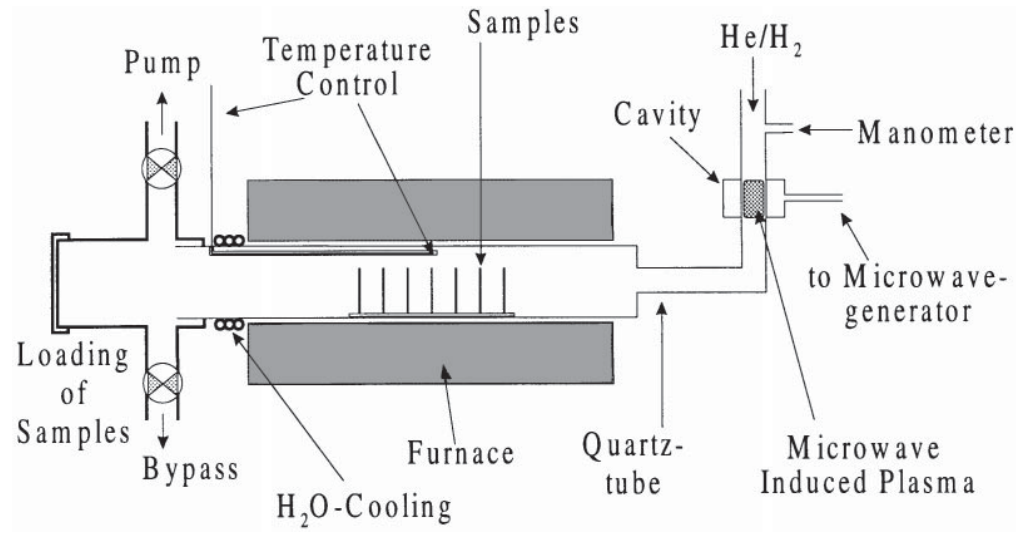

Fig. 1. Schematic diagram of the microwave-induced remote hydrogen plasma (MIRHP) device for passivation of silicon wafers and solar cells. To dissociate molecular hydrogen, microwave power is coupled through a cavity into a gas mixture consisting of $10 \% \mathrm{H}_{2}$ and $90 \% \mathrm{He}$. The atomic hydrogen, kept from recombining by the presence of the helium atoms, diffuses into the heated samples.

diffusion at $820^{\circ} \mathrm{C}$ resulting in a sheet resistance of $80 \Omega /$ sq. For a front surface passivation, a dry thermal oxide of approximately $11 \mathrm{~nm}$ was grown in a subsequent step at $900^{\circ} \mathrm{C}$. Afterwards $2 \mu \mathrm{m} \mathrm{Al}$ was evaporated onto the backside and a gettering step comprising $30 \mathrm{~min}$ at $800^{\circ} \mathrm{C}$ was applied. Photolithography for contact definition was followed by the evaporation of a $50 \mathrm{~nm} / 50 \mathrm{~nm} / 3 \mu \mathrm{m} \mathrm{Ti} / \mathrm{Pd} / \mathrm{Ag}$ front contact and a $2 \mu \mathrm{m} \mathrm{Al}$ rear contact. After cell separation and characterization including illuminated and dark IV, spectral response and reflectance measurements some cells were submitted to a MIRHP passivation and a $\mathrm{SiN} / \mathrm{SiO}_{2}$ double-layer antireflection coating (DARC) deposited by the plasma-enhanced chemical-vapor deposition (PECVD) technique.

For the hydrogen passivation a MIRHP device similar to the one described in Ref. [21] has been used as schematically shown in Fig. 1. There molecular hydrogen is separated into atomic hydrogen in a microwave plasma. In order to prevent atomic hydrogen from recombining on the way to the sample, a $\mathrm{H}_{2} / \mathrm{He}\left(10 \% \mathrm{H}_{2}, 90 \% \mathrm{He}\right.$, purity $6 \mathrm{~N}$ ) mixture was used. The temperature was measured inside the tube during the passivation treatment. The process parameters used in this study were a sample temperature of $350^{\circ} \mathrm{C}$, a gas pressure of $0.2 \mathrm{mbar}$, a gas flow of $4 \mathrm{ml} / \mathrm{min}$, a microwave power of $50 \mathrm{~W}$ and a processing time varied between 1 and $4 \mathrm{~h}$.

\section{Results and discussion}

\subsection{Homogeneity of the RGS material, benefit from the forming gas annealing}

Table 1 shows the illuminated and dark $I-V$ parameters of the four RGS cells after a short (30 min) and an additional long ( $3 \mathrm{~h}$ ) forming gas annealing (FGA) step at 


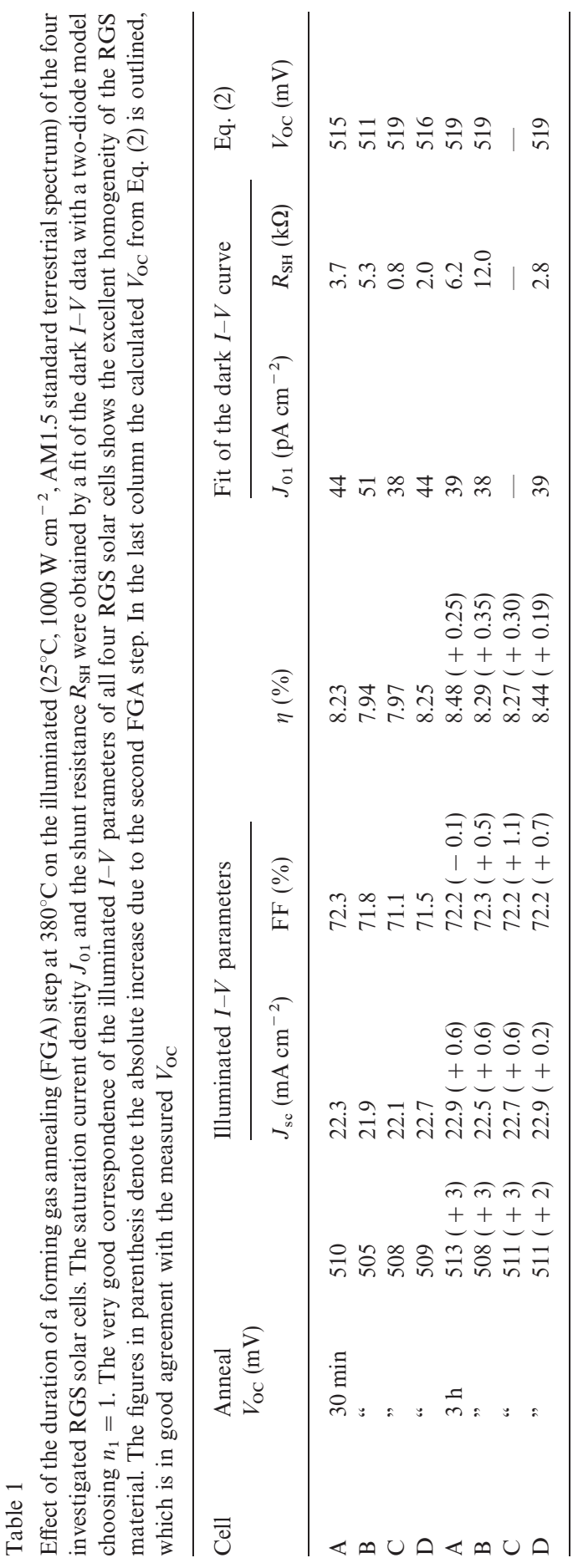


$380^{\circ} \mathrm{C}$. It is believed that the short annealing is sufficient for healing the surface damage caused by the e-gun evaporation of the front and back contact, whereas improvements of the $I-V$ parameters during the long annealing are mainly due to the passivation of defects within the RGS material. The very good correspondence of the illuminated $I-V$ parameters of all four RGS solar cells demonstrates the good homogeneity of the RGS wafer used. The nearly identical improvements of these cells due to the second long FGA suggests the same passivation mechanism for all cells and therefore a rather homogeneous distribution of the passivated crystal defects. The dark $I-V$ parameters were obtained by fitting the dark current $J_{\text {dark }}$ to the theoretical two-diode model:

$$
\begin{aligned}
J_{\text {dark }}(V)= & J_{01}\left[\exp \left(\frac{V-R_{\mathrm{S}} J_{\text {dark }}(V)}{n_{1} V_{\mathrm{th}}}\right)-1\right] \\
& +J_{02}\left[\exp \left(\frac{V-R_{\mathrm{S}} J_{\text {dark }}(V)}{n_{2} V_{\mathrm{th}}}\right)-1\right]+\frac{V-R_{\mathrm{S}} J_{\text {dark }}(V)}{R_{\mathrm{SH}}},
\end{aligned}
$$

with the saturation current densities $J_{01 / 2}$ and the diode factors $n_{1 / 2}$ of the first and second diode, the series resistance $R_{\mathrm{S}}$, the shunt resistance $R_{\mathrm{SH}}$ and the thermal voltage $V_{\text {th }}=25.7 \mathrm{mV}$. A fixed $n_{1}$ of 1 leads to very good fits with nearly equal $J_{01}$ and similar $n_{2}$ (2.13-2.27 before and 1.96-2.19 after the second FGA) for all four cells further confirming the excellent homogeneity of the RGS material. In contrast to these nearly ideal diode factors of 1 for $n_{1}$ and 2 for $n_{2}$ RGS solar cells processed in the past in our laboratory had high diode factors ( $n_{2}$ of up to 10 ) and more inhomogeneous illuminated $I-V$ parameters. The large variations in the shunt resistance $R_{\mathrm{SH}}$ between 0.8 and $12 \mathrm{k} \Omega$ have no influence on $V_{\mathrm{OC}}$ - as indicated by the nearly identical open-circuit voltages of all cells - and only a minor influence on the "fill factor" (FF) of maximal $1.2 \%$ absolute.

Because of the dominance of the first diode for voltages between 350 and $550 \mathrm{mV}$ (see Fig. 3) the open-circuit voltage $V_{\text {OC }}$ can be calculated from Eq. (1) by neglecting the second diode, $R_{\mathrm{S}}$ and $R_{\mathrm{SH}}$ [22]:

$$
V_{\mathrm{OC}}=n_{1} V_{\mathrm{th}} \ln \left(\frac{J_{\mathrm{SC}}}{J_{01}}+1\right) \text {, }
$$

with the short-circuit current density $J_{\mathrm{SC}}$. As shown in Table 1 the measured $V_{\mathrm{OC}}$ of the cells $\mathrm{A}, \mathrm{B}, \mathrm{C}$ and $\mathrm{D}$ corresponds very well with the calculated $V_{\mathrm{OC}}$ with relative deviations of below $2.2 \%$. Eq. (2) could not be applied to RGS solar cells processed in the past in our laboratory due to their highly non-ideal diode factors and to the fact that at $V_{\mathrm{OC}}$ both diodes contributed substantially to the dark current density.

\subsection{Influence of the MIRHP applied before the DARC}

On cell D a MIRHP process was applied before the deposition of a PECVD $\mathrm{SiN} / \mathrm{SiO}_{2}$ double-layer antireflection coating (DARC) resulting in absolute improvements in $V_{\mathrm{OC}}$ of $27 \mathrm{mV}, J_{\mathrm{SC}}$ of $2.8 \mathrm{~mA} \mathrm{~cm}{ }^{-2}, \mathrm{FF}$ of $2.4 \%$ and cell efficiency $\eta$ of $1.86 \%$ due to the MIRHP alone (see Table 2). After the deposition of the DARC high values 
Table 2

Dark and illuminated $I-V$ parameters of cells A and D after different processing steps

\begin{tabular}{|c|c|c|c|c|c|c|c|}
\hline \multirow[t]{2}{*}{ Cell } & \multirow[t]{2}{*}{ Processing } & \multirow[t]{2}{*}{$V_{\mathrm{OC}}(\mathrm{mV})$} & \multicolumn{3}{|c|}{ Illuminated $I-V$ parameters } & \multicolumn{2}{|c|}{ Fit on the dark $I-V$ curve } \\
\hline & & & $J_{\mathrm{sc}}\left(\mathrm{mA} \mathrm{cm}^{-2}\right)$ & $\mathrm{FF}(\%)$ & $\eta(\%)$ & $J_{1}\left(\mathrm{pA} \mathrm{cm}^{-2}\right)$ & $n_{2}$ \\
\hline \multirow[t]{3}{*}{ A } & 30 min anneal & 510 & 22.3 & 72.3 & 8.23 & 44 & 2.25 \\
\hline & $3 \mathrm{~h}$ anneal & 513 & 22.9 & 72.2 & 8.48 & 39 & 2.19 \\
\hline & DARC & 517 & 27.1 & 71.2 & 9.95 & 32 & 2.19 \\
\hline \multirow[t]{4}{*}{ D } & 30 min anneal & 509 & 22.7 & 71.5 & 8.25 & 44 & 2.27 \\
\hline & $3 \mathrm{~h}$ anneal & 511 & 22.9 & 72.2 & 8.44 & 39 & 2.03 \\
\hline & $2 \mathrm{~h}$ MIRHP & $538(+27)$ & $25.7(+2.8)$ & $74.6(+2.4)$ & $10.30(+1.86)$ & 14 & 2.05 \\
\hline & DARC & $538^{\mathrm{a}}$ & $28.5^{\mathrm{a}}$ & $72.4^{\mathrm{a}}$ & $11.1^{\mathrm{a}}$ & 14 & 2.17 \\
\hline
\end{tabular}

${ }^{a}$ Independently certified measurement at the FhG-ISE at Freiburg, Germany (8/97).

for $V_{\mathrm{OC}}$ of $538 \mathrm{mV}$ and for $\eta$ of $11.1 \%$ have been reached on this RGS solar cell. The optimal process time for the MIRHP was found to be $2 \mathrm{~h}$, whereas most of the improvements for all illuminated $I-V$ parameters occur within the first hour. Also seen are the improvements in the illuminated $I-V$ characteristics due to the second long FGA step mentioned above.

As a reference of the impact of the MIRHP in combination with a PECVD $\mathrm{SiN} / \mathrm{SiO}_{2}$ DARC the illuminated $I-V$ characteristics of cell A without MIRHP passivation is included in Table 2. Comparing cell A with cell $\mathrm{D}$ after the deposition of the DARC the MIRHP leads to absolute improvements in $V_{\mathrm{OC}}$ of $21 \mathrm{mV}, J_{\mathrm{SC}}$ of $1.4 \mathrm{~mA} \mathrm{~cm}^{-2}, \mathrm{FF}$ of $1.2 \%$ and $\eta$ of $1.15 \%$. The lower increases of $V_{\mathrm{OC}}$ and $J_{\mathrm{SC}}$ of the $\mathrm{SiN} / \mathrm{SiO}_{2}$ coated as compared to the uncoated cell can be explained by the passivation of $\mathrm{SiO}_{2} /$ emitter interface states due to the diffusion of hydrogen from the hydrogenrich SiN layer into the cell. Because of the sufficient H-passivation of cell $\mathrm{D}$ the improvements of the illuminated $I-V$ parameters are only due to the reduction of the reflectance, whereas the non-MIRHP-treated cell A improves also because of the PECVD passivation effect. This argumentation can be proven by the calculation of different contributions to $J_{\mathrm{SC}}$ from internal quantum efficiency and reflectance measurements as shown in Fig. 2.

The contribution of the passivation effect of the PECVD deposition to the total short current density increase is given by the following equation:

$$
\Delta J_{\mathrm{SC}}=\mathrm{e} \int\left(\operatorname{IQE}_{\text {after }}(\lambda)-\operatorname{IQE}_{\text {before }}(\lambda)\right)\left(1-R_{\text {after }}(\lambda)\right) F(\lambda) \mathrm{d} \lambda,
$$

with $\mathrm{IQE}_{\text {before/after }}$ being the internal quantum efficiencies before and after depositing the DARC, $\mathrm{R}_{\text {after }}$ the reflectance after depositing the ARC and $F(\lambda)$ the photon flux per wavelength interval. With an analogous equation,

$$
\Delta J_{\mathrm{SC}}=\mathrm{e} \int \operatorname{IQE}_{\text {before }}(\lambda)\left(R_{\text {before }}(\lambda)-R_{\text {after }}(\lambda)\right) F(\lambda) \mathrm{d} \lambda,
$$




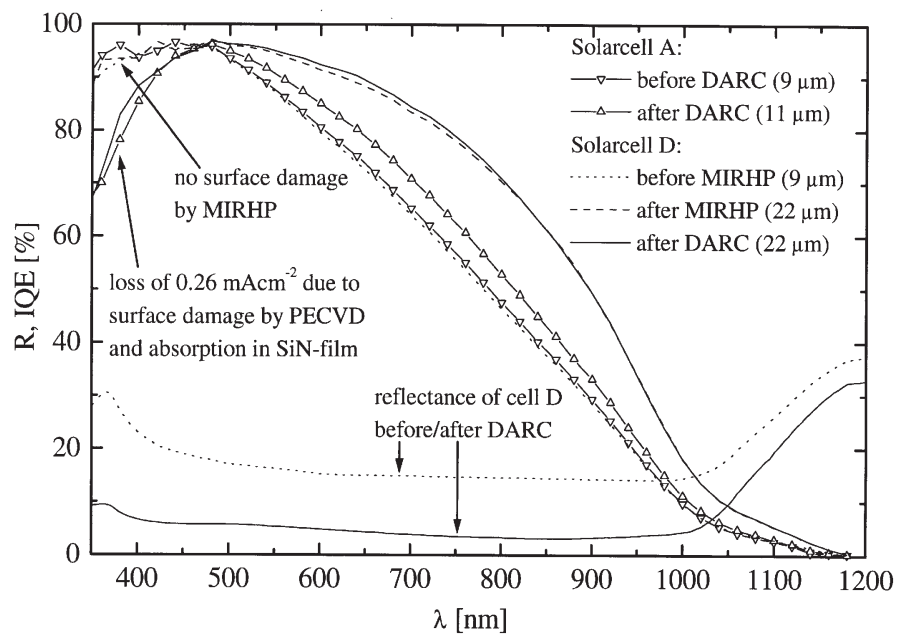

Fig. 2. IQE data of cells A and D after different processing steps. The figures in parenthesis denote the bulk minority carrier diffusion lengths determined by two-dimensional simulations. The measured reflectances of cell $\mathrm{D}$ before and after the deposition of the PECVD SiN $/ \mathrm{SiO}_{2}$ antireflection coating are included. The averaged reflectance between 360 and $1040 \mathrm{~nm}$ was $15.9 \%$ before and $4.6 \%$ after the deposition of the DARC.

with $\mathrm{R}_{\text {before }}$ representing the reflectance before depositing the ARC, the increase of $J_{\mathrm{SC}}$ due to the reduction of the reflectance can be derived. According to these equations the reduction of the reflectance of cell A leads to an increase in $J_{\mathrm{SC}}$ of $3 \mathrm{~mA} \mathrm{~cm}^{-2}$ and the passivation effect of $1 \mathrm{~mA} \mathrm{~cm}^{-2}$, which together agrees very well with the increase in $J_{\mathrm{SC}}$ of $4.2 \mathrm{~mA} \mathrm{~cm}^{-2}$ as determined by the $I-V$ measurement (see Table 2). For cell D, Eq. (4) gives an increase of $J_{\mathrm{SC}}$ of $3.2 \mathrm{~mA} \mathrm{~cm}^{-2}$ due to the reduced reflectance and Eq. (3) leads to no improvement of $J_{\mathrm{SC}}$ but a slight decrease of $0.07 \mathrm{~mA} \mathrm{~cm}^{-2}$. The difference between the increase in $J_{\mathrm{SC}}$ of $2.8 \mathrm{~mA} \mathrm{~cm}{ }^{-2}$ determined by the $I-V$ measurement (see Table 2 ) and the above calculated $3.2 \mathrm{~mA} \mathrm{~cm}^{-2}$ can be explained by the measurement uncertainty in the spectral response measurement of $2-3 \%$.

From the IQEs in Fig. 2, a plasma damage within the surface region - corresponding to wavelengths below $500 \mathrm{~nm}$ - due to a non-optimized direct PECVD deposition process can be derived. Using ellipsometric measurements it was shown that current losses due to absorption within the $\mathrm{SiN}$ film are negligible compared to the plasma damage. The damage by direct PECVD is discussed in detail in literature [23]. Recently, $J_{\mathrm{SC}}$ and $V_{\mathrm{OC}}$ decay measurements have shown that this damage can be further minimized [24] by increasing the deposition temperature. With Eq. (3) one gets in the surface region for cell D a decrease of $J_{\mathrm{SC}}$ of $0.23 \mathrm{~mA} \mathrm{~cm}^{-2}$, which is only $0.8 \%$ of the total short circuit current density for this cell. Because of the PECVD surface damage $V_{\mathrm{OC}}$ does not increase but is unchanged at $538 \mathrm{mV}$ during the deposition of the DARC as can be seen in Table 2. The expected increase of $V_{\mathrm{OC}}$ due to the increase of $J_{\mathrm{SC}}$ can be calculated with Eq. (2) to be $3 \mathrm{mV}$ or equal to $0.6 \%$ relative. 


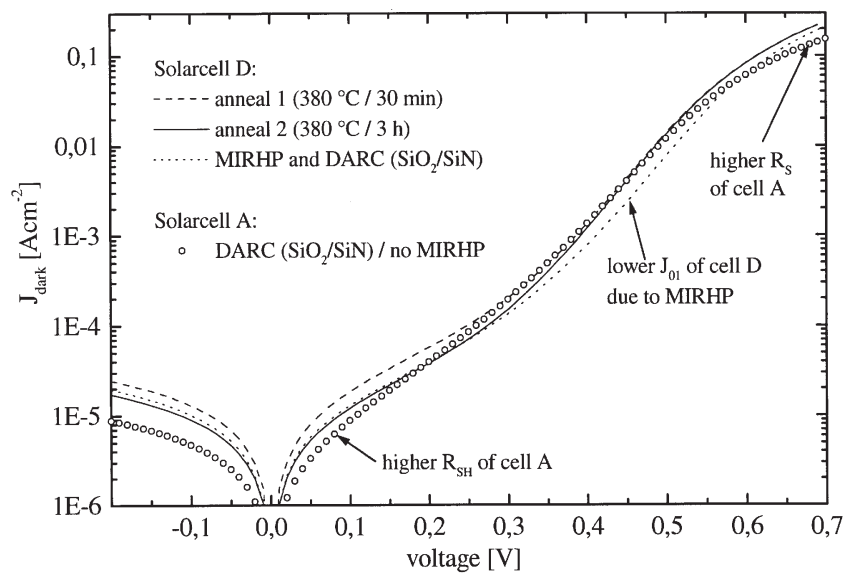

Fig. 3. Dark $I-V$ characteristics of cell $\mathrm{D}$ after different processing steps and of cell $\mathrm{A}$ after the deposition of the PECVD SiN $/ \mathrm{SiO}_{2}$ double-layer antireflection coating.

With the prevention of reductions in the fill factor by a thicker front metal grid the cell $\mathrm{D}$ could have at least a FF of $74.6 \%$ after the ARC deposition. Taking these possible improvements into account an increase in the cell efficiency by $0.4 \%$ absolute is feasible on RGS by further optimizing the solar cell process.

The positive influence of the MIRHP process on the solar cell performance can also be seen by comparing the measured dark current density $J_{\text {dark }}$ of cell $\mathrm{D}$ after different processing steps as shown in Fig. 3. A large $J_{\text {dark }}$ decrease for voltages above $260 \mathrm{mV}$ is seen after the MIRHP as compared to the measurement after the second FGA anneal. A reduction in the dark current density for small voltages below $400 \mathrm{mV}$ - this is below the voltage at the maximum power point $V_{\text {MMP }}$ of $431 \mathrm{mV}$ - could be observed after the second FGA anneal in comparison to $J_{\text {dark }}$ after the first short anneal.

A comparison of the non-MIRHP-treated cell A with cell D after the MIRHP step shows the superiority of the latter in the voltage region of $190-600 \mathrm{mV}$, which is the important region determining $V_{\mathrm{OC}}$ as well as $V_{\mathrm{MMP}}$. Below $190 \mathrm{mV}$ cell A has a lower $J_{\text {dark }}$ because of the higher shunt resistance of $6.3 \mathrm{k} \Omega$ compared to $2.7 \mathrm{k} \Omega$ of cell $D$. Both shunt resistances have no considerable influence on the fill factor. The higher series resistance of cell A of $220 \mathrm{~m} \Omega$ compared to $130 \mathrm{~m} \Omega$ of cell D which can also be seen in the shift of the $J_{\text {dark }}$ curve to higher voltages reduces the fill factor of cell A.

\subsection{Influence of the MIRHP applied after the DARC}

On cell $\mathrm{B}$, the MIRHP process was applied after the deposition of a PECVD $\mathrm{SiN} / \mathrm{SiO}_{2}$ DARC. The changes in the illuminated $I-V$ parameters of cell B after different processing steps are shown in Fig. 4 including the results of cell $\mathrm{D}$ as a reference. The large increases of all illuminated $I-V$ parameters of cell $\mathrm{D}$ after a $1 \mathrm{~h}$ 


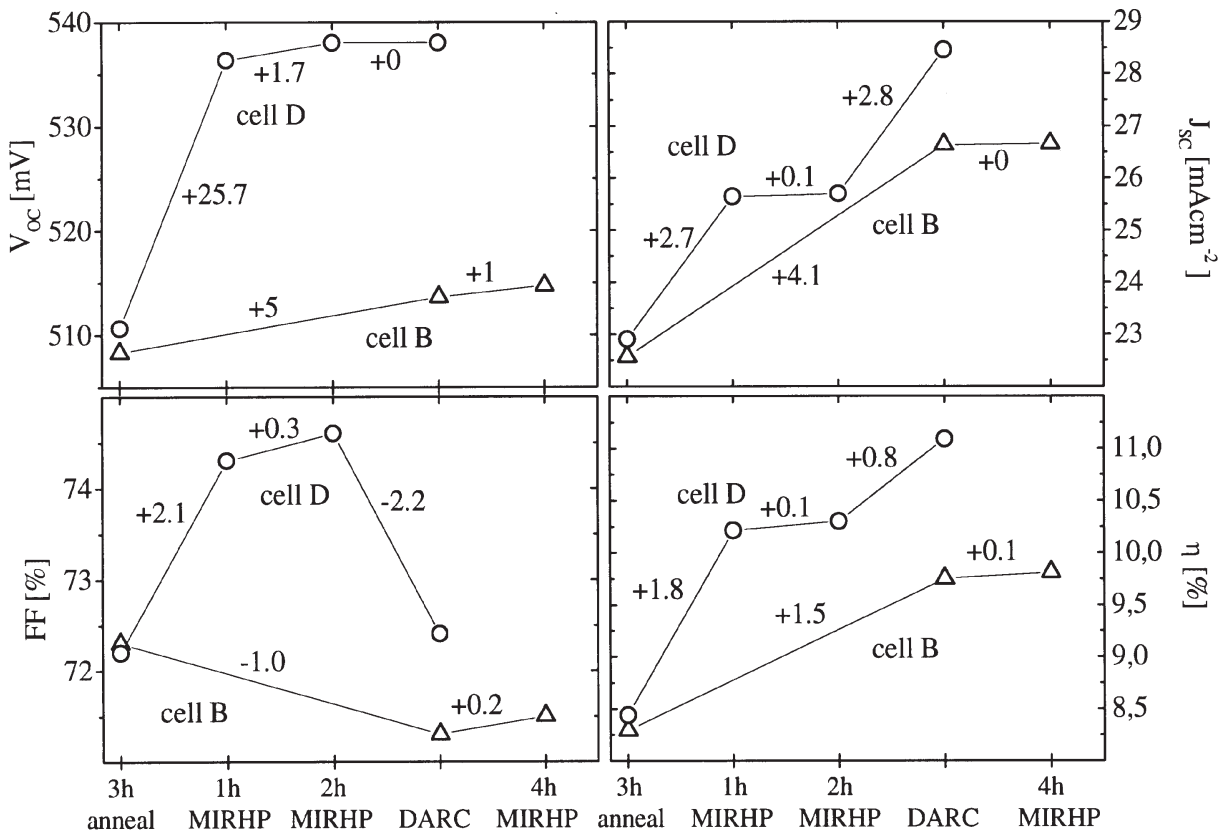

Fig. 4. Change of the illuminated $I-V$ parameters of cell $\mathrm{D}$ and cell $\mathrm{B}$ after different processing steps. On cell B the MIRHP was applied after the deposition of the DARC, whereas on cell D the MIRHP treatment was performed prior to the DARC.

MIRHP duration with only slight increases during the second hour contrasts with the results of cell B. Even after a $4 \mathrm{~h}$ MIRHP process only slight absolute increases in $V_{\mathrm{OC}}$ of $1 \mathrm{mV}, \mathrm{FF}$ of $0.2 \%$ and $\eta$ of $0.1 \%$ could be observed without changing $J_{\mathrm{SC}}$.

\section{Summary}

The microwave-induced remote hydrogen plasma (MIRHP) technique was found to be very effective in enhancing the performance of ribbon growth on substrate silicon solar cells. The MIRHP alone resulted in absolute improvements of the open-circuit voltage of $27 \mathrm{mV}$, the short-circuit current density of $2.8 \mathrm{~mA} \mathrm{~cm}^{-2}$ and the cell efficiency of $1.9 \%$ leading to an open-circuit voltage of $538 \mathrm{mV}$ and an efficiency of $11.1 \%$ confirmed at FhG-ISE, Freiburg. These are the highest reported values so far for this low-cost material. The bulk minority carrier diffusion length improved from 9 to $22 \mu \mathrm{m}$ after MIRHP passivation. The excellent homogeneity of the RGS material has been demonstrated by the good correspondence of the illuminated and dark current-voltage characteristics as well as the spectral response of different RGS solar cells. 


\section{Acknowledgements}

We would like to thank M. Keil for the helpful technical support given during solar cell processing. This work was financially supported by the JOULE 3 program of the European Commission in the frame of contract No. JOR3-CT95-0030 (DG 12WSME).

\section{References}

[1] J. Szlufcik, S. Sivoththaman, J. Nijs, R. Mertens, R. van Overstraeten, Proc. IEEE 85 (5) (1997) 709.

[2] K.J. -Hezel, Festkörperprobleme - Adv. Solid State Phys. 34 (1995) 97.

[3] Final report of the EC project, Music FM-APAS RENA CT94, EC Community Project Report, to be published.

[4] T.M. Bruton, G. Luthardt, K.-D. Rasch, K. Roy, I.A. Dorrity, B. Garrard, L. Teale, J. Alonso, K. Declerq, J. Nijs, J. Szlufcik, A. Räuber, W. Wettling, A. Vallera, Proc. 14th European Photovoltaic Solar Energy Conf. and Exhibition, Barcelona, 1997.

[5] J.H. Werner, R. Bergmann, R. Brendel, Festkörperprobleme - Adv. Solid State Phys. 34 (1995) 115.

[6] M.A. Green, S.R. Wenham, J. Appl. Phys. Lett. 65 (1994) 2909.

[7] M. Deguchi, et. al., 7th EC PVSEC, 1993, pp. 243-244.

[8] R. Brendel, Proc. 14th EC PVSEC, Barcelona, 1997.

[9] F. Wald, in: J. Grabmaier (Ed.), Crystals, Growth Properties and Applications, vol. 5, Springer, New York, 1981, p. 147

[10] M. Suzuki, I. Hide, T. Matsuyama, H. Yamashita, T. Suzuki, T. Moritani, Y. Maeda, Proc. 21st IEEE Photovoltaic Specialists Conf., Kissimmee, (1990) p. 700.

[11] H. Lange, I.A. Schwirtlich, J. Crystal Growth 104 (1990) 108.

[12] T. Vermeulen, O. Evrard, W. Laureys, J. Poortmans, M. Caymax, J. Nijs, R. Mertens, C. Vinckier, H.-U. Höfs, Proc. 13th EC PVSEC, Nice, 1995, pp. 1501-1504.

[13] H. J. Möller, M. Ghosh, M. Rinio, S. Riedel, D. Yang, Proc. 13th EC PVSEC, Nice, 1995.

[14] G. Hahn, M. Spiegel, S. Keller, A. Boueke, P. Fath, G. Willeke, E. Bucher, Proc. 14th EC PVSEC, Barcelona, 1997.

[15] H.E. Elgamel, A. Barnett, A. Rohatgi, Z. Chen, C. Vinckier, J. Nijs, R. Mertens, J. Appl. Phys. 78 (1995) 3457.

[16] M. Spiegel, P. Fath, K. Peter, B. Buck, G. Willeke, E. Bucher, Proc. 13th EC PVSEC, Nice, 1995, pp. 421-424.

[17] M. Spiegel, S. Keller, P. Fath, G. Willeke, E. Bucher, Proc. 14th EC PVSEC, Barcelona, 1997.

[18] R. Lüdemann, R.R. Bilyalov, C. Schetter, Proc. 14th EC PVSEC, Barcelona, 1997.

[19] M. Spiegel, R. Tölle, C. Gerhards, C. Marckmann, H. Nussbaumer, P. Fath, G. Willeke, E. Bucher, 26th IEEE PVSC, Annaheim, 1997, accepted for publication.

[20] G. Hahn, W. Joss, M. Spiegel, S. Keller, P. Fath, G. Willeke, E. Bucher, 26th IEEE PVSC, Annaheim, 1997, accepted for publication.

[21] C. Vinckier, A. Dumoulin, J. Corthouts, S. De Jaegere, J. Chem. Soc. Faraday Trans. 84 (2) (1988) 725.

[22] M.A. Green, Solar Cells: Operating Principles, Technology, and System Applications, Prentice-Hall, Englewood Cliffs, NJ, 1982, p. 79.

[23] A.G. Aberle, R. Hezel, Prog. Photovolt. 5 (1997) 29.

[24] B. Bitnar, R. Glatthaar, S. Keller, J. Kugler, M. Spiegel, P. Fath, G. Willeke, E. Bucher, F. Duerinckx, J. Szlufcik, J. Nijs, R. Mertens, H. Nussbaumer, F. Ferrazza, Proc. 14th EC PVSEC, Barcelona, 1997. 